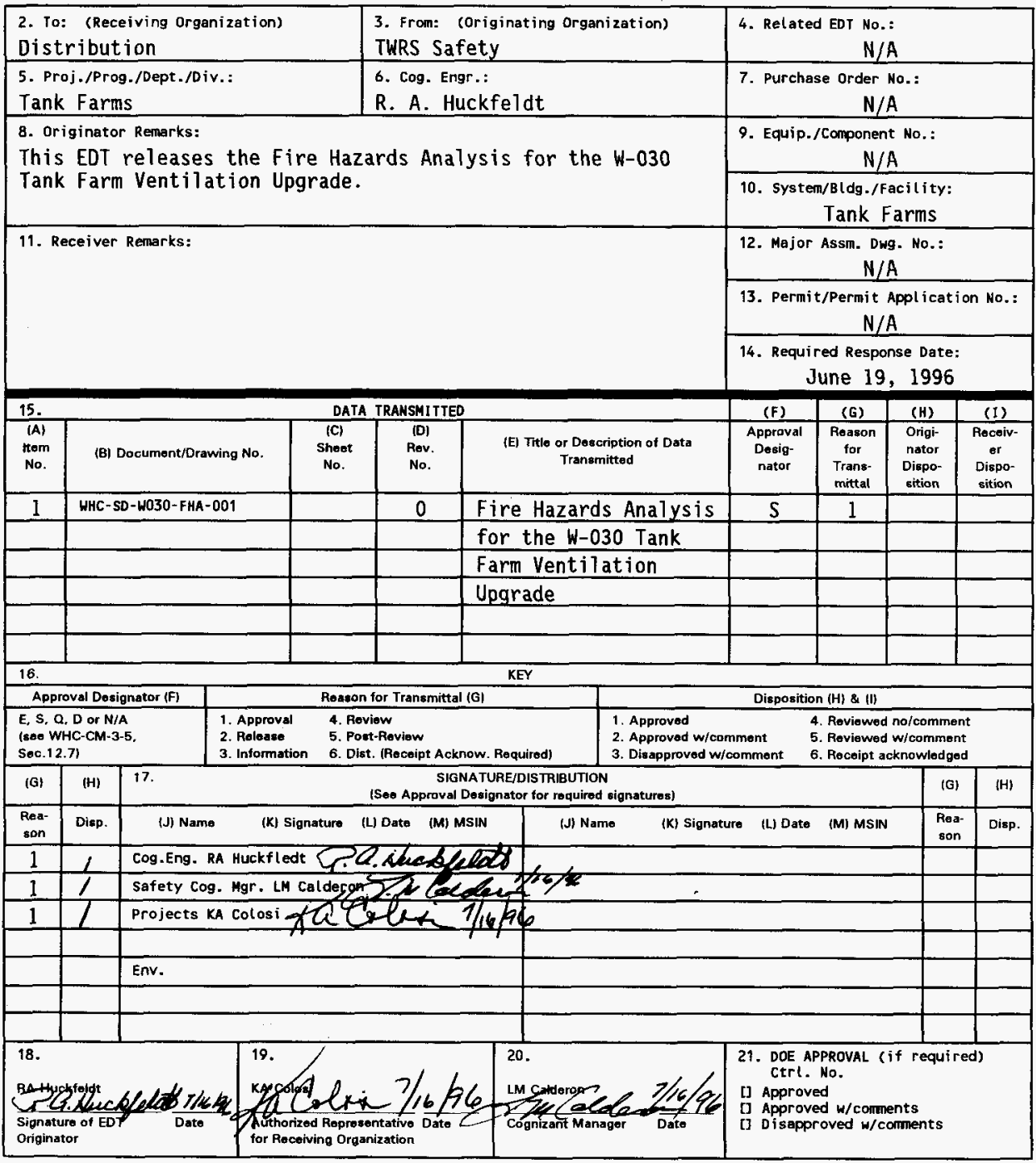

BD-7400-172-2(04/94) GEF097 


\section{Fire Hazards Analysis for the W-030 Tank Farm Ventilation Upgrade}

R. A. Huckfeldt

Westinghouse Hanford Company, Richland, WA 99352

U.S. Department of Energy Contract DE-AC06-87RL10930

$\begin{array}{llll}\text { EDT/ECN: } & 610655 & \text { UC: } 607 & \\ \text { Org Code: } & 74 G 10 & \text { Charge Code: } & \text { E70071 } \\ \text { B\&R Code: } & \text { EW3130010 } & \text { Total Pages: } 19\end{array}$

Key Words: Tank Farms, Fire Protection, 241-AZ Tank Farm, 241-AY Tank Farm, double shell tanks

Abstract: This Fire Hazards Analysis (FHA) was prepared according to the requirements of U.S. Department of Energy (DOE) Order 5480.7A, FIRE PROTECTION, 2-17-93. The purpose of this FHA is to ascertain whether the objectives of DOE 5480.7A are being met. This purpose is accomplished through a conservative comprehensive assessment of the risk form fire and other perils within individual fire areas of a $D O E$ facitity in relation to proposed fire protection. This FHA is based on conditions set forth within this document and is valid only under these conditions.

TRADEMARK DISCLAIMER. Reference herein to any specific commercial product, process, or service by trade name, trademark, manufacturer, or otherwise, does not necessarily constitute or imply its endorsement, recommendation, or favoring by the United States Government or any agency thereof or $i$ ts contractors or subcontractors.

Printed in the United States of America. To obtain copies of this document, contact: HHC/BCS Document Control Services, P.O. Box 1970, Mailstop H6-08, Richland WA 99352, Phone (509) 372-2420; Fax $(509) 376-4989$.
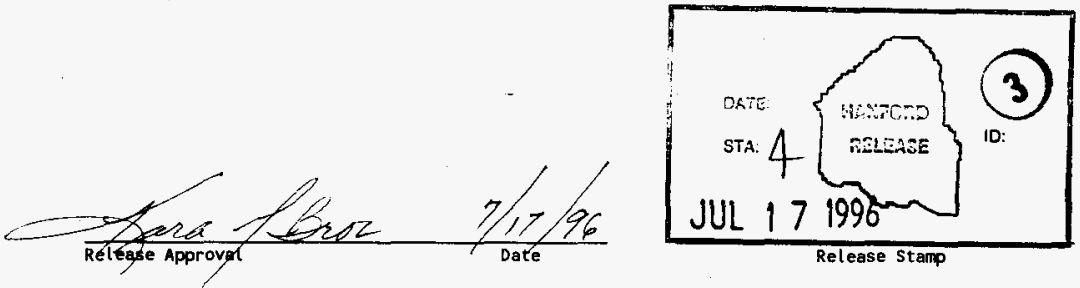

Approved for Public Release 
WHC-SD-W030-FHA-001, Rev. 0

FIRE HAZARDS ANALYSIS

FOR

W-030, TANK FARM VENTILATION UPGRADE

Westinghouse Hanford Company

July, 1996

Prepared by

R. A. Huckfeldt 


\section{TABLE OF CONTENTS}

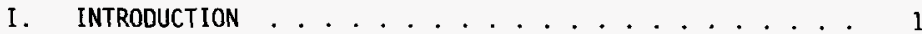

II. DESCRIPTION OF CONSTRUCTION . . . . . . . . . . 1

Ventilation Building .............. 1

Standby Generator Building . . . . . . . . . 2

Control Building ................ 2

III. FIRE PROTECTION FEATURES . . . . . . . . . . 2

IV. DESCRIPTION OF FIRE HAZARDS . . . . . . . . . 3

Ventilation Building........... 3

Standby Generator Building . . . . . . . . . . . 3

Control Building ................ 3

V. PROTECTION OF ESSENTIAL SAFETY CLASS SYSTEMS . . . . . 3

VI. LIFE SAFETY CONSIDERATIONS . . . . . . . . . . . 4

VII. CRITICAL PROCESS EQUIPMENT . . . . . . . . . . . 4

VIII. HIGH VALUE PROPERTY .............. 4

IX. DAMAGE POTENTIAL: MAXIMUM CREDIBLE FIRE LOSS (MCFL), MAXIMUM POSSIBLE FIRE LOSS (MPFL) . . . . . . . . . 4 Ventilation Building ............... 4 Standby Generator Building . . . . . . . . . . . . . 6 Control Building . . . . . . . . . . . 6

X.FIRE DEPARTMENT RESPONSE ............. 7

XI. RECOVERY POTENTIAL . . . . . . . . . . . . 7

XII. POTENTIAL FOR A TOXIC, BIOLOGICAL, AND/OR RADIATION INCIDENT DUE TO A FIRE . . . . . . . . . . . 7

XIII. EMERGENCY PLANNING . . . . . . . . . . . 8

XIV. SECURITY AND SAFEGUARDS CONSIDERATIONS RELATED TO FIRE PROTECTION . . . . . . . . . . . . . . 8

XV. NATURAL HAZARDS IMPACT OF FIRE SAFETY . . . . . . 8 Floods ...................... . . 8 High Winds ...................... . 9 Earthquake ................. . . 9 Lightning. $\therefore \therefore \therefore \therefore$

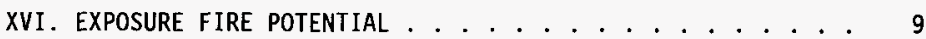
XVII. SUMMARY AND CONCLUSIONS ............ 9 


\section{ABBREVIATIONS}

AWWA American Water Works Association

DCG Derived Concentration Guide

DOE U.S. Department of Energy

FHA Fire Hazards Analysis

HEGA high-efficiency gas absorber

HEPA high-efficiency particulate air

HVAC heating, ventilating, and air conditioning

MCFL maximum credible fire loss

MPFL maximum possible fire loss

MRP Management Requirements and Procedures

NFPA National Fire Protection Association

PVC polyvinyl chloride

RFAR radio fire alarm reporter

RLIP Richland Field Office Implementing Procedure

SDC Standard Design Criteria

UBC Uniform Building Code

UCRL University of California Lawrence Radiation Laboratory

WHC Westinghouse Hanford Company 
WHC-SD-W030-FHA-001, Rev. 0

Page 1

\section{INTRODUCTION}

This Fire Hazards Analysis (FHA) was prepared according to the requirements of U.S. Department of Energy (DOE) Order 5480.7A, FIRE PROTECTION, 2-17-93. The purpose of an FHA is to ascertain whether the objectives of DOE $5480.7 \mathrm{~A}$ are being met. This purpose is accomplished through a conservative comprehensive assessment of the risk from fire and other perils within individual fire areas of a DOE facility in relation to proposed fire protection. This FHA was based on conditions set forth within this document and is valid only under these conditions.

Project $W-030$ addresses the replacement of the primary tank ventilation subsystem of the 241-AY and 241-AZ Tank Farms. These tank farms were constructed in the 1970s and each consists of two double-shelled tanks which store radioactive liquid wastes. Current Hanford waste volume projections identify a need to use the four tanks beyond the year 2000. This life expectancy mandates upgrades to, and/or replacement of, some of the tank farm subsystems to extend their useful life and to comply with current codes, standards, and regulations. Along with the replacement of the primary tank ventilation subsystem, project $W-030$ includes the construction of three new buildings to house the new subsystem. The scope of this FHA is limited to these three buildings.

The design of each facility is in accordance with DOE Order 5480.7A, "Fire Protection, " 1987 and DOE Order 6430.1A, "General Design Criteria", 1989, and Richland Field Office Implementing Procedure (RLIP) 5480.7, "Fire Protection," 1990. Subsequent to the initiation of this design, the Richland Office of the Department of Energy issued the Richland Implementing Directive (RLID) 5480.7 , "Fire Protection", 1994. This document mandates compliance with the Filter Plenum Fire Protection Criteria contained in the DOE Fire Protection Resource Manual. Although this document was not part of the Functional Design Requirements for this project, a review was conduct to assure that this design adequately addressed the new requirements. This design is judged equal/equivalent to those requirements.

\section{DESCRIPTION OF CONSTRUCTION}

The three buildings constructed are the Ventilation Building, the Standby Generator Building, and the Control Building. The building structures conform to the requirements for Safety Significant nonreactor facilities as defined in Hanford Plant Standard, Standard Design Criteria (SDC), SDC-4.1, "Design Loads for Facilities," as required by Westinghouse Hanford Company (WHC) manual, WHC-CM-4-46, Section 9, "Safety Analys is Manual, Safety Structures, Systems, and Components." Areas of the buildings which house Safety Significant equipment are designed to withstand Safety Significant Design Basis Accidents.

Ventilation Building:

The new Ventilation Building is a permanent 272 square meters $(2,928$ square feet) structure with a design life of 30 years. It is divided into two distinct areas.

One area houses the process ventilation equipment, instrumentation, and electrical equipment. There are dual primary ventilation filter trains and controls, which are isolated by fire shield walls rated at a minimum of 2 hours. This area of the building is a reinforced concrete structure. The interior concrete walls are painted with special protective coating to help in 
WHC-SD-W030-FHA-001, Rev. 0 Page 2

decontamination. The exterior walls are covered with an exterior insulation and finish system.

The second area houses a fire protection riser, strainers, and instrumentation. This area of the building is an insulated metal stud structure with a metal exterior and interior panels on a reinforced concrete slab. There is a second floor penthouse above the twin filter rooms. This penthouse is an insulated pre-engineered clear span rigid frame structure with a metal liner inside and houses the building high-efficiency particulate air (HEPA) filtered exhaust system.

Standby Generator Building:

The new standby generator building is a permanent 90 square meters (968 square feet) structure with a design 1 ife of 30 years. It is divided into distinct areas.

One of the areas house the diesel-engine driven generator and standby electrical distribution equipment. All backup equipment is isolated by fire shield walls rated at a minimum of 2 hours. This area of the building is a cast-in-place, reinforced concrete, insulated structure with an exterior insulation and finish system. The interior concrete walls are painted.

The second area houses electrical distribution equipment, a fire protection riser, strainers, and instrumentation. This area of the building is an insulated metal stud structures with a metal exterior and interior panels on a reinforced concrete slab-on-grade.

Control Building:

The control building is a 107 square meters (1,152 square feet) structure housing the operator control station and engineering work station portion of the monitor and control system. The building is an insulated pre-engineered clear span rigid frame metal structure that is 9.75 by 9.14 by 3.05 meter (32 by 30 by $10 \mathrm{ft}$.) clear height. The building has a computer floor at 0.15 meter ( 6 in.) above grade level, and a recessed reinforced concrete slab with its upper surface about 0.61 meter (24-in.) below computer floor. Al1 interior walls will be constructed of metal studs with painted gypsum wallboard facing.

\section{FIRE PROTECTION FEATURES}

Automatic sprinkler protection, fire alarms, and detection are provided in each facility as required by DOE Orders 5480.7A, "Fire Protection," 1987 and 6430.1A, 1989, and Richland Field office Implementing Procedure (RLIP), "Fire Protection," 1990. The sprinkler systems are designed per National Fire Protection Association (NFPA) 13, "Installation of Sprinkler Systems," 1989, for an Ordinary Hazard Group 2 occupancy. The automatic sprinkler systems, as well as the fire alarm, are safety Class Significant and are attached so they will not damage any other Safety Significant items below them in the event of a design base accident. Two fire hydrants service the ventilation subsystem facilities. One hydrant is located approximately 24 meters ( $80 \mathrm{ft}$.) north of the Generator Building, and the second is located approximately 21 meters $(70 \mathrm{ft}$.$) south of the Control Building.$

The Ventilation Building and the Generator Building both have dry pipe sprinkler systems, while the Control Building uses a wet pipe system. Three new $15.24 \mathrm{~cm}$. (6-in.) raw water lines extend from a $30.48 \mathrm{~cm}$. (12-in.) raw water loop to each of the three buildings and supply water to the three 
building sprinkler systems. The new $15.24 \mathrm{~cm}$. (6-in.) raw water lines provide the required fire protection water for the facilities. A new $5.08 \mathrm{~cm}$. (2-in.) raw water line provides makeup water to the cooling towers. The lines are direct-buried polyvinyl chloride (PVC), installed in accordance with American Water Works Association (AWWA) C900, "Polyvinyl Chloride (PVC) Pressure Pipe, 4 in. through 12 in., for Water Distribution."

The buildings have manual pull stations at each exit door. The fire alarm systems from the three buildings report to the fire alarm control panel in the Control Building. Alarms and trouble signals transmit to the fire department via a new radio fire alarm reporter (RFAR), and is compatible with existing equipment.

The facilities are constructed of noncombustible materials in accordance with NFPA 220, "Standard on Type of Building Construction," Type II, 000 . The concrete slab in the primary ventilation system area has been lowered to contain any fire water.

\section{DESCRIPTION OF FIRE HAZARDS}

Ventilation Building:

In the Ventilation Building there is approximately 150 meters $(500 \mathrm{ft})$ of exposed wiring in cable trays. There are also things such as fan motors and electronic equipment which would be considered credible ignition sources.

Standby Generator Building:

In the Generator Building there is a diesel generator with its 946 liters (250 gallon) fuel tank, 19 liters (20 quarts) of 011 in the crankcase, batteries, and related engine equipment. Wiring in the building is in conduit and the backup battery has a fan to the outside to exhaust any possible buildup of hydrogen. Heat from the generator is exhausted through louvered openings in the walls of the generator room. Possible sources of ignition include the spare battery and other electrical connections and equipment, as well as unexpected heat release from the generator or even accidental direct contact between the manifold of the generator and a transient combustible.

Control Building:

The Control Building contains an estimated maximum of 300 meters ( $1000 \mathrm{ft}$.) of exposed electrical wiring below the raised computer floor. The floor itself is of all steel framing and construction, with high-pressure laminated vinyl panels. There is also some electronic equipment in plastic housings. Ignition could credibly be caused by the electronic equipment or connections.

\section{PROTECTION OF ESSENTIAL SAFETY CLASS SYSTEMS}

Safety Structures, Systems, and Components (SSCs) are identified according to their importance in performing or maintaining a required safety function. A defense-in-depth approach to facility safety ensures that no single barrier (engineered or administrative) is relied on to prevent or mitigate the release of hazardous materials to the environment. Defense-in-depth SSCs provide successive barriers to prevent and mitigate uncontrolled releases of hazardous material, and to protect the SSCs that perform this function.

Safety Class SSCS prevent or mitigate releases to the public that would otherwise exceed the offsite radiological risk guidelines, or prevent accidental nuclear criticality. Safety Significant SSCs prevent or mitigate 
releases of radiological materials to onsite workers and toxic chemicals to the offsite public and onsite workers. This includes barriers that are judged to substantially contribute to defense-in-depth independent of quantitative analysis. Safety Significant also describes worker safety SSCs that protect the facility worker from serious injury due to hazards not controlled by institutional safety programs.

The design for this project contains no essential Safety Class SSCs included in this project. All three buildings contain Safety Significant SSCs, such as sprinklers. WHC-SD-WM-SARR-039 will more completely address this subject.

\section{LIFE SAFETY CONSIDERATIONS}

The occupancy classification is a Special Purpose Industrial facility with low or ordinary hazard per NFPA 101, "Code for Safety to Life from Fire in Buildings and Structures." The facilities were designed to meet the requirements of NFPA 101 . Means of egress and other life safety features meet this standard.

\section{CRITICAL PROCESS EQUIPMENT}

Critical process equipment is that equipment whose continued integrity is essential to ensure the operability of safety class items in the event of a design basis fire. Refer to WHC-SD-WM-SARR-039 for this item.

\section{HIGH VALUE PROPERTY}

For the purposes of this FHA, high value property is defined as equipment having a value of more than $\$ 1$ million. No fire area in the ventilation building contains equipment valued over this $\$ 1$ million limit.

No high value property is located in the Generator Building.

No high value equipment was noted for the Control Building. The equipment used to control the ventilation subsystem is of substantial value, but does not exceed $\$ 1$ million.

IX. DAMAGE POTENTIAL: MAXIMUM CREDIBLE FIRE LOSS (MCFL), MAXIMUM POSSIBLE FIRE LOSS (MPFL)

Maximum Credible Fire Loss (MCFL) is defined, in DOE 5480.7A, to be:

The property damage that would be expected from a fire, assuming that:

(1) All installed fire protection systems function as designed.

(2) The effect of emergency response is omitted except for post-fire actions such as salvage work, shutting down water systems, and restoring operation.

The DOE 5480.7A definition of Maximum Possible Fire Loss (MPFL) is:

The value of the property, excluding land, within a fire area, unless a fire hazards analysis demonstrates a lesser (or greater) loss potentia]. This assumes the failure of both automatic fire suppression systems and manual fire fighting efforts. 
Estimates for building and content values are $\$ 1,500,000$ and $\$ 1,100,000$ respectively. Because the construction is non-combustible and the building is fully sprinklered throughout, the Ventilation Building fire areas have MCFL figures which are less than $\$ 250,000$.

The MPFL for this fire area is based on a fire starting from an electrical short or from a maintenance operation. The combustibles located in the $E / I$ Rooms $A$ and $B$ are very limited and consist of electrical wiring in 6 inch trays or conduits, motors, breakers, controllers, and items used for maintenance work. Combustibles are estimated to be less than 68 kilograms (150 pounds) for each of these rooms. The Stack Monitor Room has even less combustibles, estimated to be less than 23 kilograms (50 pounds). Each area has a lack of continuity of combustibles. These rooms are separated from themselves and Filter Rooms $A$ and $B$ by cast in place concrete walls and $a$ concrete roof. Combustibles in Filter Room $A$ or $B$ include breakers, monitors, and maintenance items, estimated to be less than 23 kilograms ( 50 pounds) of combustibles. In addition each filter train is covered with a one inch thick "rubber like material" insulation blanket. This material covers about 14 square meters (150 sq. ft.) of the filter unit. This is about $57 \mathrm{kilograms}$ (125 pounds) of combustibles. Each train contains two 0.61 by 0.61 meters (24 by 24 inch) HEPA filter units ( 4.5 kilagrams (10 pounds) of combustibles each) and 39 kilograms ( 85 pounds) of carbon in the absorbers. Electrical wiring is in conduits. Filter Trains $A$ and $B$ are separated by 2 hour fire shield walls.

A fire (minimal duration) in either E/I Rooms A or B would damage some equipment. This would cause the shut down of either train $A$ or $B$, but not both. Replacement of damaged equipment would be required. These two rooms are clean. A fire would not release any contamination. Damages would be about $\$ 750,000$ including equipment replacement, fire fighting, and cleanup costs.

A fire in the Stack Monitor Room would damage the equipment that was originally involved, but would not spread. Shut down is not expected of the Ventilation facility. This is a clean area. A fire would not release any contamination. Damages would be about $\$ 250,000$ including equipment replacement, fire fighting, and cleanup costs.

A fire (minimal duration) in either Filter Room A or B would not damage the equipment to a point that it would require replacement. The shut down of either train $A$ or $B$ is expected, but not both. These three areas are expected to be kept clean and thus a fire would not release any contamination. A fire, even if all the combustibles were consumed, would be of such a limited duration that the ignition of the filter media or the charcoal would not be possible. A fire in these room is not expected to breach the building structure and contamination will be contained in the building.

A possible fire source in the filters from the a buildup of radioactive materials on the filters or charcoal was evaluated. This buildup would have to generate adequate heat to ignite the filter media or the charcoal. In order to assure that the significant radioactive build up can not occur, an OSR 1 imit of $200 \mathrm{mrem} /$ hour is being established. Using a computer mode1, a $200 \mathrm{mrem} /$ hour field corresponds to 0.12 Curies of $\mathrm{Cs} / \mathrm{Ba}-137$ in the charcoal filters. Using the project Environmental Process Flow Diagram for the radionuclides in the exhaust stream, the heat loading was calculated. At the $200 \mathrm{mrem} /$ hour level, the heat generated by captured radionuclides is approximately 0.043 watts. At this level there is not sufficient heat to cause the carbon to burn. In order to implement this control, 0SD-T-151-00019 will limit the carbon filter to less than $200 \mathrm{mrem} /$ hour measured at the filter housing. This reading will be taken weekly. The $200 \mathrm{mrem} / \mathrm{hour}$ is based on measuring Cs/Ba-137 which emits gamma energy. 
It should also be noted that the existing design/installation has automatic interlock features which sense train temperatures and in case of a high temperature alarm closes train inlet/outlet gas tight valves. This isolates the train while, simultaneously, the redundant train is placed on 1 ine. This interlock cannot be overridden.

A fire inside the filter units is not considered to be a credible fire based on the controls above.

Standby Generator Building:

Estimates for the building and contents for the Generator Building are $\$ 400,000$ and $\$ 200,000$ respectively. Because the construction is non-combustible and the building is fully sprinklered throughout, the Generator Building fire areas have MCFL figures which will be less than $\$ 250,000$.

The MPFL for this fire area is based on a fire starting from an electrical short, fuel leak, engine fire, or from a maintenance operation. Combustibles located in the Transfer Switch Rooms 1 and 2 are very 1 imited and consist of electrical wiring in conduits, breakers, controllers, and items used for maintenance work. Combustibles are estimated to be less than 11 kilograms (25 pounds) for each of these rooms. Construction of this building is concrete. Two hour fire shield walls are provided to separate the Transfer Switch Rooms from the rest of the facility. The Generator Room has 946 liters (250 gallons) of diesel fuel plus other combustibles that if ignited could spread and cause damage to this room and the other parts of this building.

A fire (estimated to last 5 minutes or less) in either Transfer Switch Rooms would damage some of the equipment and may cause the shut down of either train $A$ or $B$, but not both. Shut down of the trains would only happen if the generator was providing the power for the unit. Replacement of damaged equipment would be required. These two rooms are clean. A fire would not release any contamination. Damages would be about $\$ 250,000$ including replacement, fire fighting, and cleanup costs.

A fire in the Generator room could spread with limited damage to other parts of the building. Shut down is not expected of the Ventilation facility unless the equipment was being operated on standby power. This is a clean area. A fire would not release any contamination. Damages would be about $\$ 250,000$ including replacement, fire fighting, and cleanup costs.

Control Building:

Estimates for the building and contents for the Control Building are $\$ 150,000$ and $\$ 200,000$ respectively. Because the building is fully sprinklered, the Control Building has an MCFL which will be less than $\$ 250,000$.

The MPFL for this fire area is based on a fire starting from an electrical short, equipment failure, or from a maintenance operation. This building has steel frame wall and roof with insulated metal siding and roof. The combustibles located in the control Room consists of electrical wiring in conduits, breakers, computers, office furniture, paper, supplies, and others items that would be expected in a office occupancy. Combustibles are est imated to be $73 \mathrm{kgrams} / \mathrm{sq}$. meter ( 15 pounds/sq. ft.) which if ignited will cause major building damage.

Due to the combustible loading a fire would cause completed loss of this building. The shut down of either Ventilation Train A or B is not expected. 
Total replacement would be required. This is a clean area and a fire would not release any contamination. Damages would be about $\$ 400,000$ including equipment replacement, fire fighting, and cleanup costs.

\section{$X$. FIRE DEPARTMENT RESPONSE}

Currently, the standard response to an alarm condition in the 200 East area is from the 200 Area Fire Station. According to the Fire Marshall of the Hanford Fire Department, the response time to the site of this ventilation subsystem facility is in the range of 5-7 minutes. Simultaneously, a crew will be dispatched from the 100 Area Fire Station with an estimated response time of 12-14 minutes.

A Pre-Fire Plan, which provides the Fire Department with information about a structure and its contents to assist in the response to a fire in that structure, has been prepared by the Fire Department.

\section{RECOVERY POTENTIAL}

Because of the duality of ventilation equipment and other Safety Significant items, a Design Basis Accident would not likely result in a loss of function of the facility. However, if a fire caused a power failure or damage to power equipment, equipment not tied to the standby power system could be debilitated. Temporary recovery from this condition would be forthcoming within the first 24 hours through the use of a portable generator tied into the existing wiring. Procurement and reconstruction of damaged areas of the ventilation subsystem facility would constitute full recovery and could take 6 months or more to complete.

XII. POTENTIAL FOR A TOXIC, BIOLOGICAL, AND/OR RADIATION INCIDENT DUE TO A FIRE

During normal operation the building heating, ventilating, and air-conditioning (HVAC) system provides three different pressure zones in the ventilation facility. The electrical instrumentation areas are called Zone 3 , the space enclosing the process ventilation systems is Zone 2, and the process cooling vault itself is Zone 1 . In order to maintain the required negative pressure, as well as to dilute any potentially flammable gases, the rates of air changes for each zone are as follows. The air supplied to Zone 3 is at a rate of six air changes per hour and is recirculated to the supply system. The Zone 2 space receives approximately eight air changes per hour from which roughly one-half exfiltrates through HEPA filters to the Zone 1 area, while the other half goes directly through the HEPA exhaust system. The Zone 1 area is exhausted to a cleanup system consisting of a pre-filter, HEPA filters, and exhaust fan. The cleanup system is composed of two identical systems; one is the operational system and the other the backup system.

In event of a fire, process ventilation is required to remain active in order to maintain a negative pressure in the waste storage tanks. In the very unlikely event of failure of both of the process ventilation systems, the potential for radiological release would be slightly increased. The tank could not be held at a negative pressure, but would return to atmospheric pressure. The tank could be isolated with valves but the spread of small amounts of radiological contamination could still occur through migration of airborne particulates in leakage paths. Portable equipment would be needed to re-establish a negative pressure and assure containment.

The interconnecting duct between the two HEPA filter units of the process ventilation system passes through a two hour rated fire wall. This duct is 
$25.4 \mathrm{~cm}$. (10 inch) Schedule 10 steel pipe with manual isolation valves on both ends. These valves are in the normally open position. Other manual and automatic valves will be closed and will provide necessary isolation. The duct is provided with a two hour or greater fire wrap to insure that a room fire will not damage the duct. Based on the very low fire loading of the room, in the area of the duct, and the operations of the system, a fire will not breach the duct and spread from one room to the other room. A fire damper is not installed in the duct as it would not be possible to check the damper yearly for operation as required by NFPA 80 due to potential contamination of the duct.

\section{EMERGENCY PLANHING}

The most important part of the emergency planning for this ventilation subsystem facility is the Pre-Fire Plan which was be developed by the Hanford Fire Department. In addition to this plan, emergency planning includes the fire safety training given to each employee as part of the general employee training and new employee training. The fire department personnel are adequately trained and equipped to deal with the types of hazards that are associated with this facility, such as high-efficiency gas absorber (HEGA) and HEPA filters, and other items which may be contaminated, and hazardous materials operations in genera?.

\section{SECURITY AND SAFEGUARDS CONSIDERATIONS RELATED TO FIRE PROTECTION}

This ventilation subsystem facility is located within the 200 East Area and it is assumed that this isolation will assure freedom from any significant criminal element. Furthermore, there will not be any sensitive material or any special nuclear material in the buildings or on the site which would require special security considerations.

There are no security barriers or special coordination requirements that would hinder the fire department's access. Previous fire department responses to the 200 East Area have shown that the existing procedures are adequate.

\section{NATURAL HAZARDS IMPACT OF FIRE SAFETY}

While it is not possible to predict what types of catastrophic events may occur on the Hanford site, we can use past experience as a guide to judge how facilities may or may not be in danger from natural hazards.

Floods :

The 200 Areas are situated on a plateau of such an elevation that the buildings and other facilities located there are not susceptible to even a "probable maximum flood" of the Columbia River Basin, as postulated by the U.S. Army Corps of Engineers (ERDA 1975).

The probable maximum 24-hour precipitation, estimated to occur once in 1,000 years is $7.6 \mathrm{~cm}$. (3 inches) (Stone et al., 1983). Because of the below-grade construction of some of the building slabs, these buildings may experience flooding under extremely wet conditions. In the case of the ventilation Building, the floor in the primary ventilation system area has been lowered for the express purpose of containing any fire water so there should not be any problem with flood water. The recessed slab under the computer floor in the Control Building is not intended to catch water and may contain cables linking pieces of electronic equipment together. Water in this cavity would be of concern and could cause loss of equipment or control, but no water detection device is provided. 
High Winds:

Wind of tornado proportions is quite uncommon in the Pacific Northwest. Washington state has an average tornado frequency of less than one per year. Within a 50 mile radius of the Hanford site, only five small tornadoes were recorded from 1950 to 1970 (Fujita, 1976). The last recorded tornado occurred in 1983, north of Pasco, about 24 kilometers (15 miles) east of the Hanford site.

High winds, on the other hand, occur fairly often at Hanford. Personnel and equipment doors of the Safety Significant structures are reinforced to resist impact from a wind-generated missile as defined by SDC-4.1 and University of California Lawrence Radiation Laboratory (UCRL) 15910, "Design and Evaluation Guidelines for Department of Energy Facilities Subjected to Natural Phenomena Hazards," criteria.

Earthquake:

According to the Uniform Building Code (UBC), eastern Washington is in seismic zone $2 B$, which indicates a region of $10 \mathrm{w}$-to-moderate seismicity. This does not, however, rule out the possibility of earthquake. A strong enough earthquake would have the potential to completely destroy the structures, but this magnitude of earthquake is unlikely. The Ventilation Building and the Generator Building are designed for a moderate hazard seismic event in accordance with UCRL 15910 and SDC 4.1, Rev 11, 9-6-89. The Control Building is designed for a low hazard seismic event in accordance with UCRL 15910 and the UBC.

\section{Lightning:}

A direct strike to a building could cause structural damage to the point of impact and would also cause a voltage surge through the structural frame of the building. This voltage surge could cause substantial damage to electronic components in the structure. A lightning protection risk assessment has been conducted for the facility and surrounding area, per NFPA 780 . This assessment shows that loss due to lightning would be a conservative light to moderate risk. Thus the facility does not warrant lightning protection and none is provided.

\section{EXPOSURE FIRE POTENTIAL}

The buildings of this ventilation subsystem facility are relatively remote from other facilities as related to fire exposure potential. The buildings' proximity to one another likewise is of little concern. The Ventilation Building and the Generator Building are separated by 7.6 meters ( $25 \mathrm{ft}$ ). This distance is ample, considering that both buildings are constructed primarily of reinforced concrete which is noncombustible. The Control Building is made of metal and while it is more susceptible to fire exposure than the other buildings, it is separated by a minimum of 7.6 meters $(25 \mathrm{ft}$.$) from them. The$ exposure hazard between these three buildings would not be considered to be substantial, even at much closer distances. The existing condition is in compliance with NFPA 80A, "Recommended Practice for Protection of Buildings From Exterior Fire Exposures."

\section{SUMMARY AND CONCLUSIONS}

The risk of fire loss in this three-building facility is well managed through the placement of walls of fire rated construction and through the use of fire sprinkler systems for fire suppression throughout. Combustible material 
WHC-SD-W030-FHA-001, Rev. 0

Page 10

loadings are held to a minimum in each fire area and exposure dangers are mitigated by physical separation. The protection of this facility and its contents, as well as the safety of its occupants, are adequately assured.

Water supplies for this location do not have a second supply as required by DOE 6430.1A. A second water source is to be provided by Project B-604 which is currently under construction. 
WHC-SD-W030-FHA-00Y, Rev. 0

Page 11

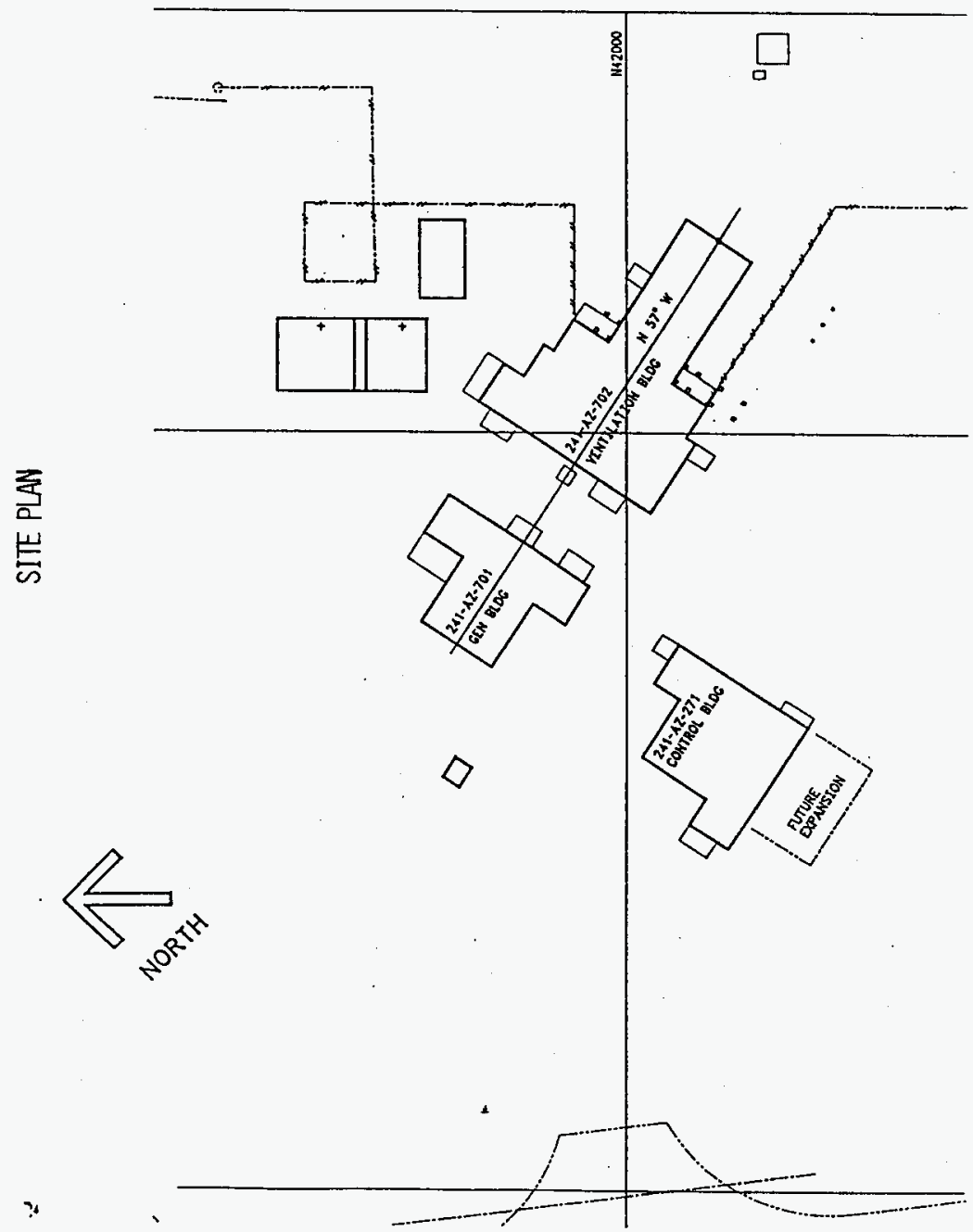


WHC-SD-W030-FHA-001, Rev. 0

Page 12

氞

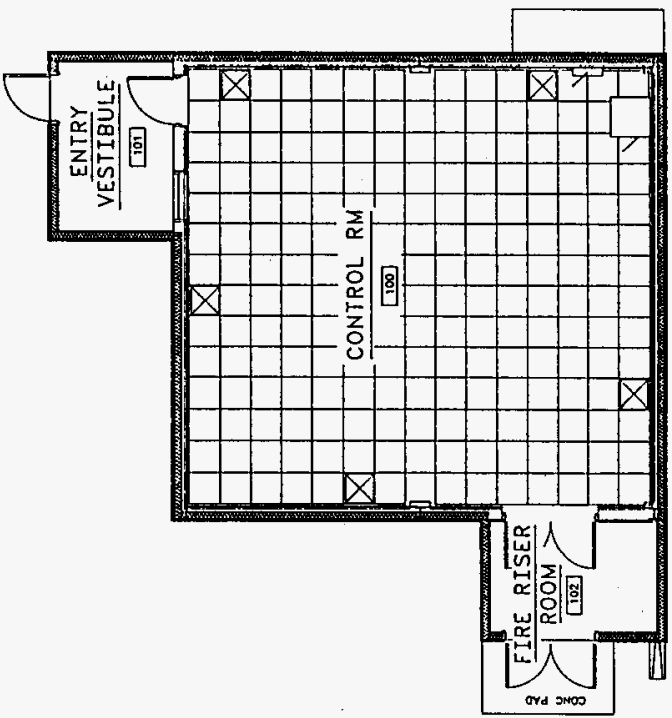

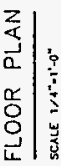

$n=\frac{\text { I }}{\frac{1}{2}}$ 
WHC-SD-W030-FHA-001, Rev. 0 Page 13

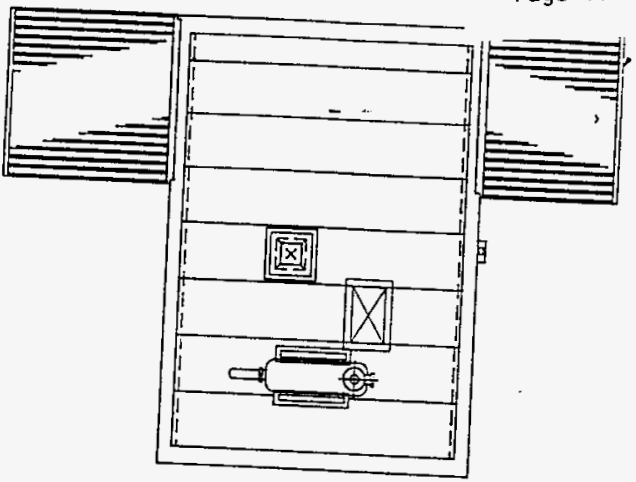

$z$
$a$
$a$
0
0
0

告

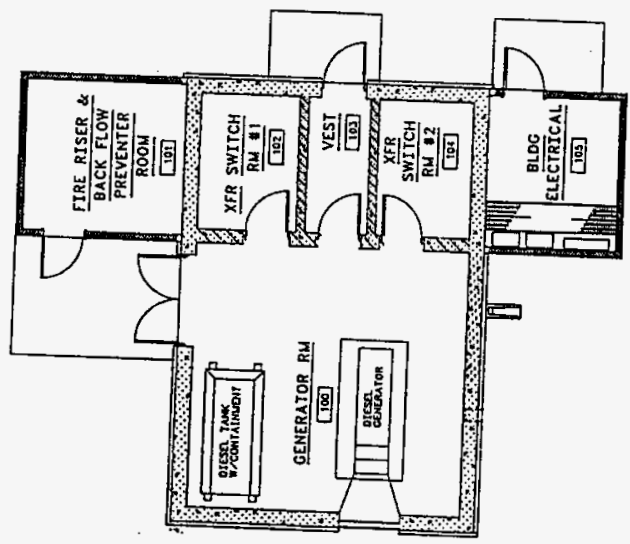

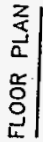

L/ 


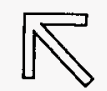

NORTH

\section{VEPTILATION RUILING}

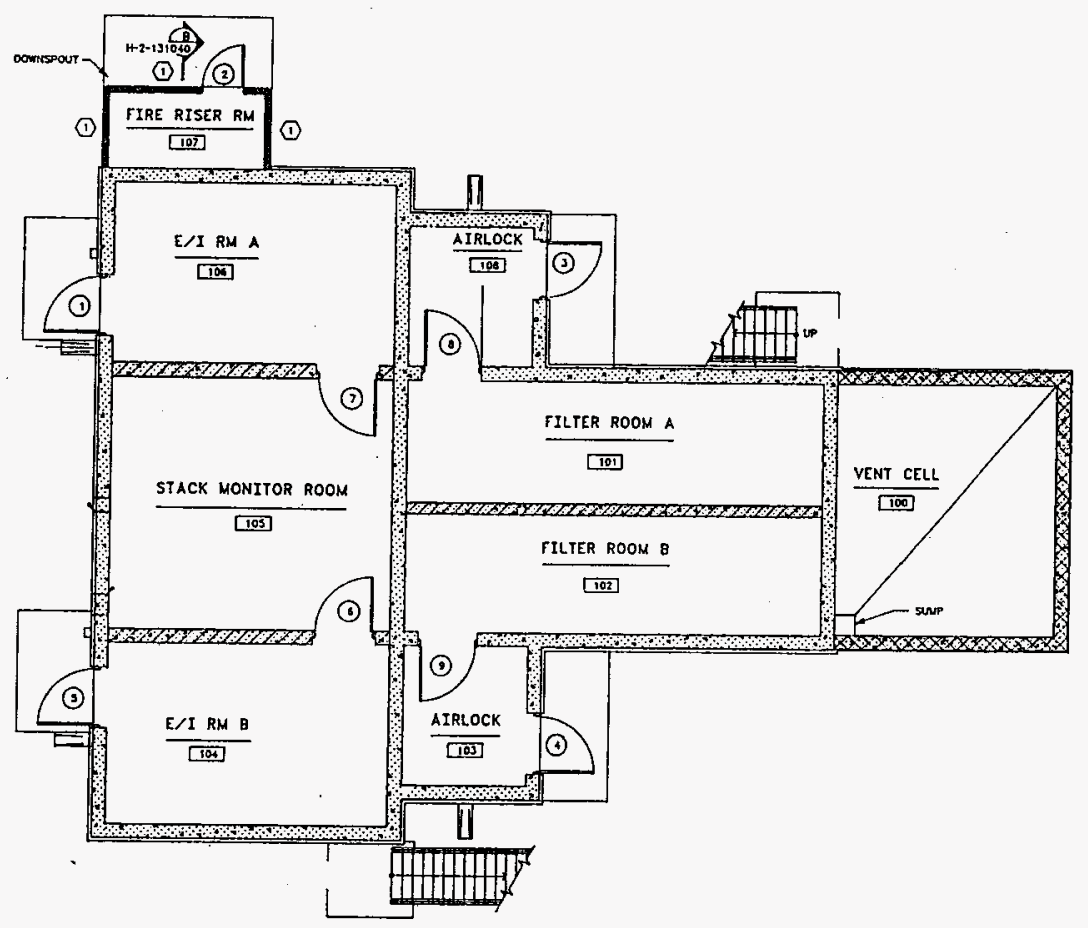

FIRST FLOOR PLAN 
WHC-SD-W030-FHA-001, Rev. 0

Page 15

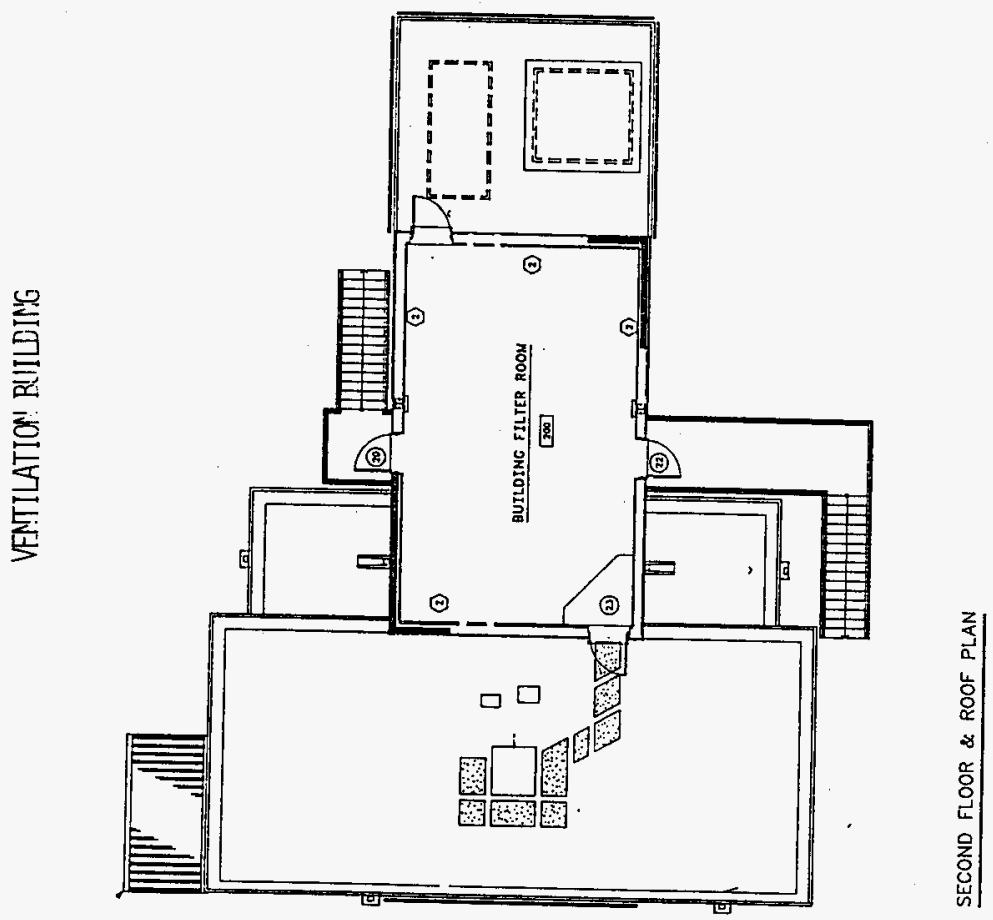

$\perp$

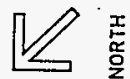




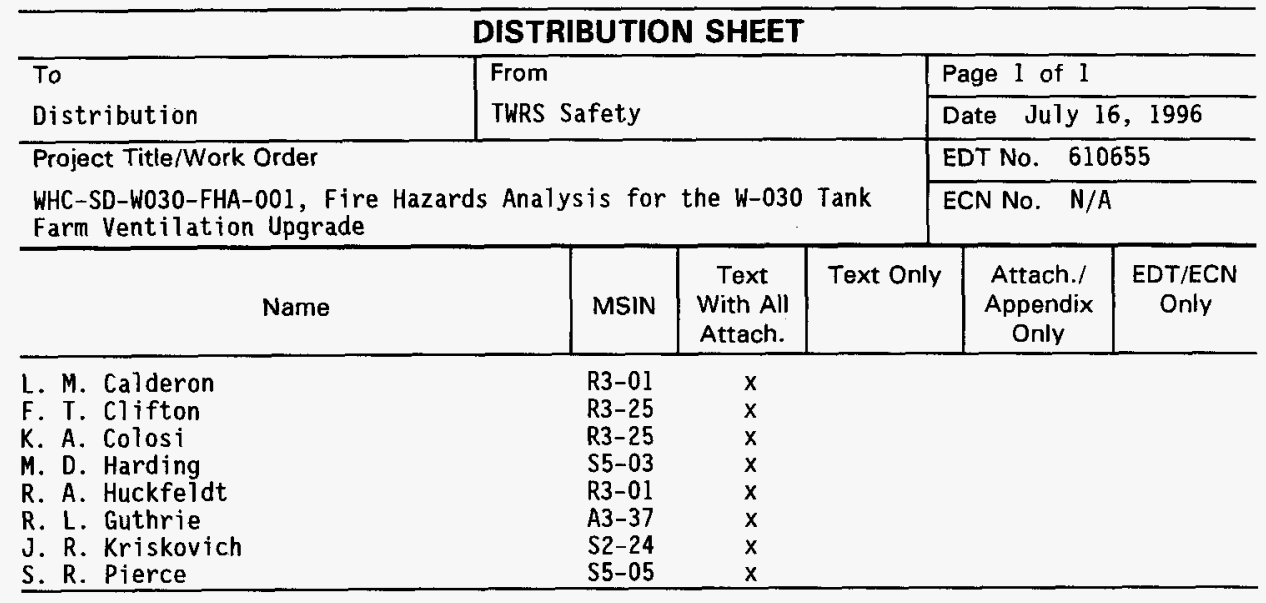

